\title{
Exporting the Western university
}

\author{
As Western universities establish lucrative satellite programs overseas, they promise to draw new parts of the globe \\ into the scientific endeavor. Faculty recruitment, however, emerges as a hurdle on the way to excellence.
}

A

Western college degree represents a major status boost in many non-Western societies. Universities in the US and the UK have long benefited from streams of graduate students paying maximal tuition, then working as graduate and postdoctoral trainees for low compensation. Recently, however, there has been an interesting turn of the tide. Instead of funding scholarships for their citizens to acquire a prestigious education abroad, some countries have launched ambitious programs to entice overseas universities to their own shores. These offers have found enthusiastic takers among some research universities especially in the US, who seek to expand their brand overseas and increase their cash flow. Although it is too early to predict how successful these programs will become, recruiting faculty to these overseas campuses is emerging as a major hurdle.

Duke University recently partnered with the National University of Singapore (NUS) to open a graduate medical school, dubbed Duke-NUS GMS. The school, closely modeled on the Duke School of Medicine, is run by Duke administrators. Duke's chair of psychiatry, Ranga Krishnan, was just appointed as its second dean. The initial class of 26 medical students will earn Duke MD degrees together with medical degrees from NUS. However, the whole collaboration is financed entirely by Singapore. Duke-NUS GMS is recruiting heavily and is also currently in the midst of a worldwide search for a director of their Neuroscience and Behavioral Disorders program.

The petroleum-rich states of the Arabian Peninsula are also keen to attract Western colleges. Career-oriented business and engineering programs have been most popular, but the sciences are now catching up. Weill-Cornell Medical College has run a medical school, WCMC-Q, in Doha, Qatar, since 2002. Students are admitted by the same criteria that apply to the New York campus. They are taught by Weill-Cornell faculty (though many lectures are delivered by video) and earn Weill-Cornell MD degrees. Although WCMC-Q has focused solely on producing top-notch physicians - the first class graduated this spring - the school very recently announced the launch of a "worldclass biomedical research program," underwritten by $\$ 45$ million from the Qatari government. They are currently seeking faculty members in several areas, including neurobiology.

Perhaps the boldest move comes from New York University (NYU), which plans to build an entire residential research university with a fully integrated liberal arts college in Abu Dhabi. Classes at NYU Abu Dhabi are projected to start in fall of 2010. Abu Dhabi is financing the entire project and has also made an initial donation of \$50 million to NYU's home campus.

At first glance, this bonanza of additional jobs may seem a great opportunity for young scientists struggling to find good academic positions in the US or UK. Nevertheless, political, cultural and language differences conspire to make the recruitment of top Western (or Western-trained) faculty to branches in Asia or the Middle East a formidable task. The states that currently offer this generous funding do not always score high on the basic freedoms of speech, press, religion and assembly, nor do many of them grant equal rights to women and minorities. Fairness before the law can be shaky, especially when a case would pit a foreigner against an influential citizen. In 2003, the British neurologist Simon Shorvon, then head of the Singapore National Neuroscience Institute, was accused of ethical lapses and fired from his position, only to be replaced by his deputy, who happened to be a member of Singapore's most powerful political family. Medical oversight agencies and courts in the UK later found the accusations against Shorvon groundless, and a doctors' advocacy group even issued a warning to British doctors contemplating positions in Singapore.

Perhaps for these reasons, not all Western universities who have received well-funded partnership offers from Singapore or Arabian states have jumped at the chance. The British University of Warwick in 2005 declined to build an undergraduate campus in Singapore over concerns about academic freedom. Yale University considered establishing an arts institute in Abu Dhabi, but refused to grant Yale degrees there; the project was therefore abandoned. Johns Hopkins established a medical clinic and biomedical research center in Singapore in 1998, but the Singapore government withdrew all funding from the research center in 2006 after it failed to attract the anticipated high caliber of investigators.

So how can prestigious universities deliver a top-notch education and grant their coveted degrees, without a similar caliber of faculty in the outposts as at the home base? Fulton Wong, a professor of ophthalmology at Duke who recently joined Duke-NUS GMS, is optimistic that the positions can be filled. However, this remains to be seen, and the problem is even more acute when considering as ambitious an expansion of the university as NYU is planning. Several projects, such as WCMC-Q, rely heavily on distance learning, and it is unclear whether the education these universities provide overseas (and the degrees they will confer) is truly equivalent to what US students currently get.

Regardless of how successful the cash-hungry universities are in spreading their 'brands', these brave projects will expose students in other parts of the world to the scientific method and provide additional opportunities to develop scientific programs in the host countries. Over time, the recruitment problem may resolve itself as Asian and Middle Eastern countries educate and nurture academics from their own citizenry. And in the interim, the far-flung branches of Western academia might also help contribute to promoting basic freedoms and equal rights. If nothing else, we expect that entirely new populations of students will get an opportunity to dive into scientific inquiry and experience its rewards.

View background material on Connotea at

http://connotea.org/user/NatNeurosci/tag/editorial200808. 